\title{
HISTORICAL TIMBER STRUCTURES IN ADANA-TEPEBAĞ SETTLEMENT AND CONSOLIDATION APPROACH WITH MODERN TIMBER PREFABRICATED SYSTEMS
}

\author{
KERIMMCAN APAK ${ }^{1}$ \\ ${ }^{1}$ Adana Alparslan Türkeş Science and Technology University \\ Balcalı Mahallesi, Çatalan Caddesi, No:201/1 Sarıçam, 01250 \\ Adana, Turkey \\ e-mail: kerimcanapak@atu.edu.tr, https://web.atu.edu.tr/kerimcanapak
}

Keywords: Timber Frame Structure, Brick Masonry, Prefabricated Systems

\begin{abstract}
Adana-Tepebağ settlement is located in the south-east part of the Anatolia close to the Mediterranean Sea. This settlement is located in the center of the city, composed of unique architectural heritage with different plan typologies of historical structures, used of varied materials such as timber, brick, and stone. Traditional timber structural systems are widely used in this area.

In this research, proposing a consolidation method for traditional timber structures with modern prefabricated systems in the frame of technological prefabrication criteria. Such as several joint details, lifting and storage properties, and fabrication state of the construction element and minimum waste ideal of the timber material ${ }^{[2]}$.

This research is done in a historical settlement in Adana-Tepebağ. The state of the timber structures is in a high damaged condition as a result of the lack of maintenance in an extended period. Consequently, there is a need for a consolidation method for the maintenance of historical structures in that area. These analyzing criteria are applied to a historical timber structure in that settlement on a case study for showing the progress of this methodological approach.

The progress of the methodology is composed of three main steps;

1-The damage and corrosion analysis of skeleton timber structure.

2-The decision method within the frame of technological prefabrication criteria of modern timber prefabricated elements on the damaged parts of this structure.

3-Data's, which are collected from the previous two stages, are analyzed and compared. This methodological approach expected to be a rational decision method for the consolidation of historical structures in the Tepebağ settlement. Significantly partly damaged timber structures consolidation is very critical in the frame of budget and the authenticity of the building.
\end{abstract}




\section{INTRODUCTION}

Tepebağ settlement is located in the center of Adana city, which is placed in the southeast part of Anatolia near the Mediterranean border. This settlement is an important historical area of traditional Turkish houses and Tepebağ tumulus, which is the first settlement of Adana city. In the historical period, Tepebağ is very dominant in Adana city's economic, social, physical, social development. The location is very significant related to its history and the civilizations which are passed through. The first known localized civilization in Adana city is Hittite's in B.C. XV. After this period, one after another, Assyrians, Egyptians, Romans, Seljuks, and Ottomans are settled in Adana [7].

The first organized construction facility of the Adana was done in the Ramazanoğlu seignory period (1352-1517). The most symbolic buildings were constructed at that time. Natural catastrophes of the floating of the Seyhan River and the nomad population were adverse effects of the development of the built environment until the economic revolution of Adana in the $19^{\text {th }}$ century $[5,7]$.

Before the $19^{\text {th }}$ century, adobe construction was frequently used in Adana houses. After the second half of the $19^{\text {th }}$ century, the construction quality of traditional Adana houses was developed, and the traditional architectural style of the region was defined. Durability of the structures get important; therefore, timber skeleton system with masonry walls was used instead of adobe construction $[5,7]$.

The historic urban site of this area is losing its authentic characteristics and importance for

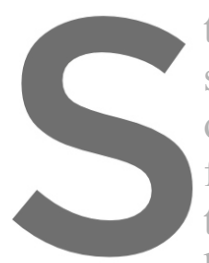
the lack of maintenance settlement are prepared of workforce, constructio for these historical hous timber houses proposed a rational methodolc houses.
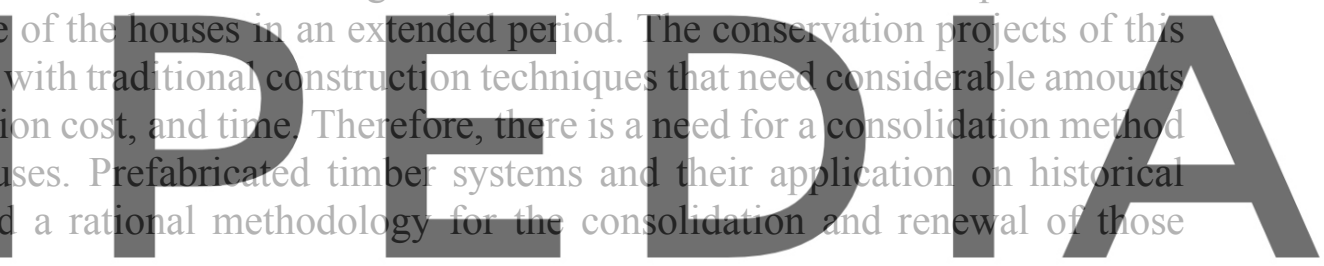

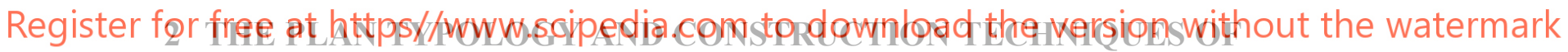
TRADITIONAL HOUSES IN ADANA-TEPEBAĞ SETTLEMENT

Until the mid of 19th century, the traditional Adana houses are built upon one-floor mudbrick with earthen built flat roof. With the help of industrialization and commercial movement, street development and housing construction is progressed. At the end of the $19^{\text {th }}$ century and beginning of the $20^{\text {th }}$ century, magnificent traditional houses are built near the Seyhan river and extended all around the area. Tepebağ settlement was located in the historic commercial center of the Adana city (Figure 1). Therefore, the housing units are located around this area. This settlement is very significant and catchy with its narrow adjacent oriented traditional timber houses on curvilinear streets $[4,5]$.

Traditional Tepebağ timber houses were built upon the historical commercial area; for this reason, the units of the houses were changed according to the functional needs. The ground floor is used for storage and cellar. The upper part of the house is used for a residential unit. Some houses are designed with a mezzanine floor which called 'Cihancuma'. The idea of planning 'Cihancuma' is getting a vista from the Seyhan river $[4,5]$.

The houses are designed according to the number of family members. The most important aspects of designing Turkish houses are socio-cultural and socio-economical aspects, as well 
as local construction materials and climate. Thus stone, timber, and mud-brick material are frequently used in those buildings. Beside of this, the temperature is another factor for organizing the functional units. Therefore, traditional Adana timber-framed houses are designed and planned in the direction of the prevailing wind. Rooms and sofas are the main functional units that had an identical design and layout of the house. The place of the rooms on the plan is determined by the location sofas [4].

The plan typology of traditional Adana houses is classified according to the placement of the sofa. The functional interpretation of the sofa is an entrance hall for the bedrooms. Gathering activities and entertainment are the main functional specifications of the sofa in the traditional Turkish living routine.

The first type of house; the sofa is located inside of the plan. In this type, the sofa is surrounded by rooms. The balconies are placed in front of the sofas, which are the common space for the family members and common areas for distribution between the functions. In general, in those types of houses, there are leisure spaces for summer on the top of the sofas. In the second type of house, the sofa is located outside of the plan and oriented to the north-south direction. The upper part of the sofas is open to the exterior without any barrier; therefore, the occupants can benefit from the sunlight and prevailing wind. The sofa expanded to the street from its adjacent wall by doors and windows, which brought a visual enrichment to the facade $[6,12]$.
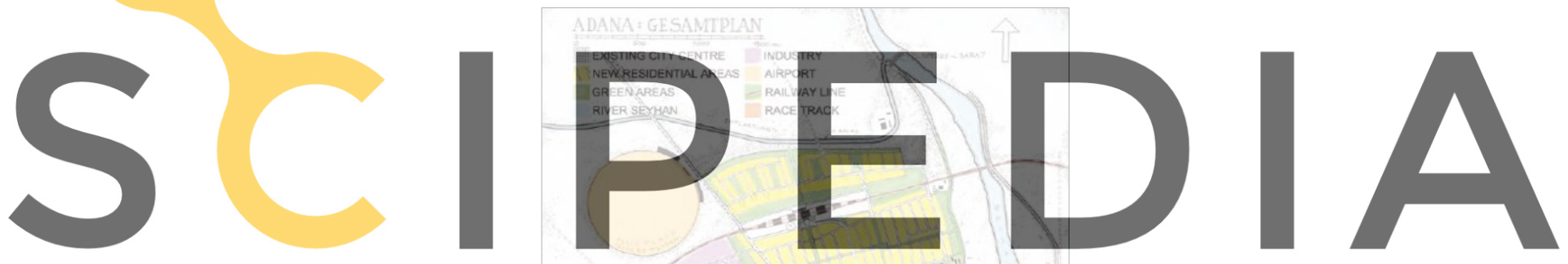

Register for free at https//www.scipedia.com to download the version without the watermark

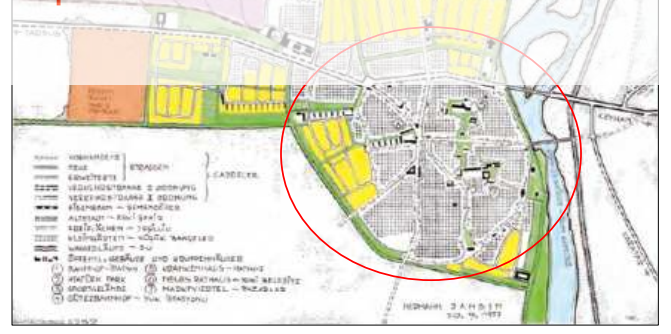

Figure 1: Adana-Tepebağ settlement, the city plan prepared and drawn by Hermann Jansen in 1940 [11]

There are two types of construction systems in traditional timber houses in Adana-Tepebağ. In the first system, the load-bearing stone walls are constructed on the ground floor with $50 \mathrm{~cm}$ to $60 \mathrm{~cm}$ thick. On the upper floor, the wall is built with a timber-framed filled with mixed brickwork. In the second system, the load-bearing walls are constructed on the ground floor with 50 to $60 \mathrm{~cm}$ thick with mixed brickwork masonry supported with timber beams. On the upper floor, the timber-framed walls are filled with mixed brickwork masonry. The height of the masonry walls is approximately $3.5 \mathrm{~m}$ to $4 \mathrm{~m}$. The lap joints are used with timber tie-beam and timber frame elements which are used inside the load-bearing walls $[1,10]$. 
Some unique architectural elements, such as cantilevered floors, balconies, oriels, decorative elements, and eaves, are used in traditional Turkish houses in Adana. Oriels are used for visual integration of interior spaces through the street. Besides, cantilevered floors are used for creating an enlarged space in interior areas (Figure 2). In traditional timber Adana houses, the parts of the building, such as staircases, doors-windows, roofs are constructed in unique timber design and construction techniques $[1,10]$.

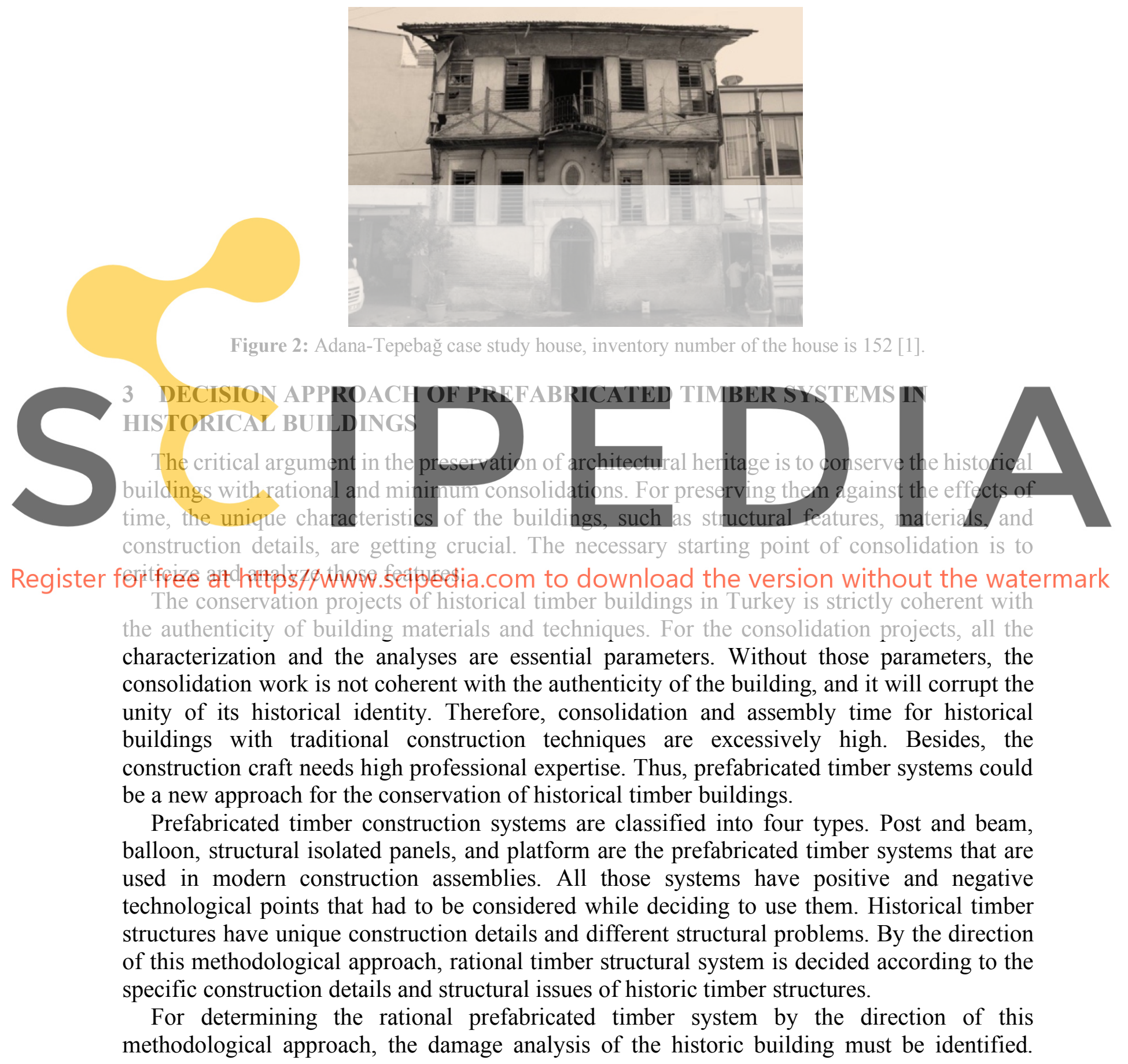


Besides, technological parameters of prefabricated timber structures are compared and examined according to the data of the historic building.

The technical principles of prefabricated timber structures are classified under the headline of four main timber prefabricated structural systems. The technological aspects and their relation with timber structural systems are listed as follows.

\subsection{Production of the timber parts}

In this criterion, timber parts of the structure are assembled in the construction site or a factory. This criterion affects the construction time and the quality of the details. Factory based production of timber building parts always brings high craft with quality control and minimizing assembly time in construction sites. Besides, adverse atmospheric conditions are not affected by timber parts and not occur any deformations. Also, timber waste material management is done in factory assembly. The suitability of the production criteria of the prefabricated timber structure is parallel with its factory assembly rate $[2,8]$.

\subsection{Assembly of the timber parts}

The number of prefabricated timber panels which are joined in a construction site or factory and their lifting ease determined the assembly criteria. The number of features and the joint details are increased the time of the construction. Post-beam and balloon systems are mostly constructed in site. Those systems composed of small elements that need a considerable amount

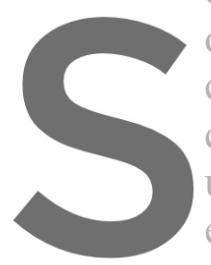
of time for assembly. However, structural
composed of big construction units such a
construction parts of walls and slabs is done
units in site needs les time compared with other
ease of prefabricated timber dements are a c
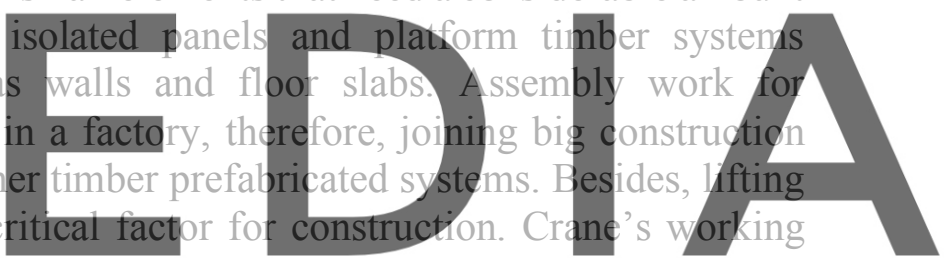

area and the dimensions of the timber parts are essential for the assembly $[2,8]$.

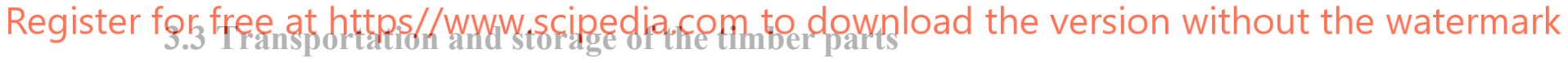

According to the construction system, prefabricated timber parts are assembled in factories or construction sites. If the timber parts are joined in a factory, the transportation limits of the highway correlatively the size of the timber parts have to be considered. Besides, if the timber parts are joined in a construction site, the closed storage area and size of timber elements get their importance.

The storage area of the timber parts inside of the construction site is brought an additional cost for the construction. Hence, the prefabricated timber systems which need storage place inside of the construction site are not or less suitable to this parameter $[2,8]$.

Technological parameters of the prefabricated systems and their suitability are compared and matched on the table 1. There are three main considerations for prefabricated timber elements related to technical parameters. If the parameter fills the requirement, it is labeled as 'respected'; if not, it is marked as 'not respected'. If the parameter fills the requirement by preconditions, then it is labeled as 'depended'. 
Table 1: Prefabricated timber systems and their suitability with technological parameters [2,8].

\begin{tabular}{|l|l|l|l|l|}
\hline & \multicolumn{4}{|c|}{ Prefabricated timber systems } \\
\hline Parameters & Post-beam & Balloon frame & $\begin{array}{l}\text { Structural } \\
\text { isolated panels }\end{array}$ & Platform \\
\hline Production & Not respected & Not respected & Respected & Respected \\
\hline Assembly & Not respected & Not respected & Respected & Respected \\
\hline Lifting ease & Respected & Depended & Depended & Depended \\
\hline Transportation & Respected & Depended & Depended & Depended \\
\hline Storage & Depended & Depended & Respected & Respected \\
\hline
\end{tabular}

\section{CASE STUDY CONSTRUCTION SYSTEM AND DAMAGE ANALYSIS}

For examining and receiving appropriate data for the methodological approach, general structural condition of the case study building, damage status for each floor was analyzed.

\subsection{Structural System}

The case study of this research is chosen from the historical timber house in Tepebağ-Adana. The inventory number of this building is 152 in the archives of the Adana endowment office. This building is composed of ground, mezzanine and first floor with load-bearing walls. The load-bearing wall is

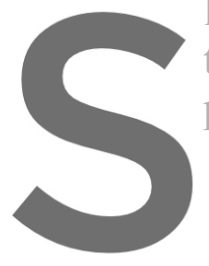
timber tie beams. Each plate materials (Figure 3
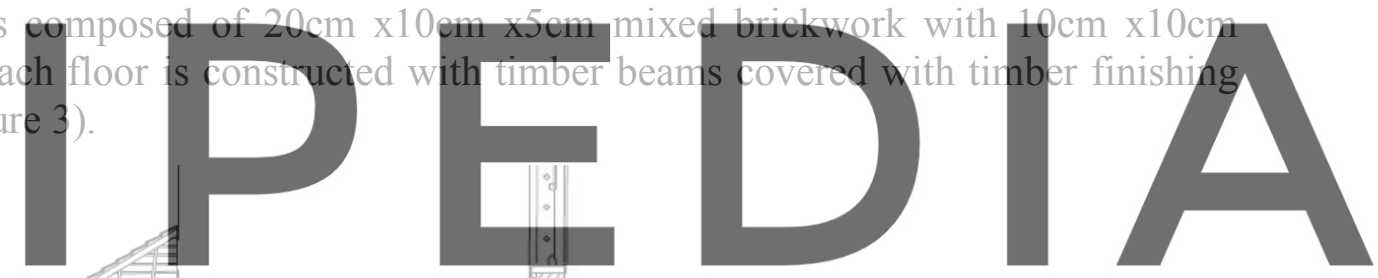

Register for free at https//www.scipedia.com to download the version without the watermark
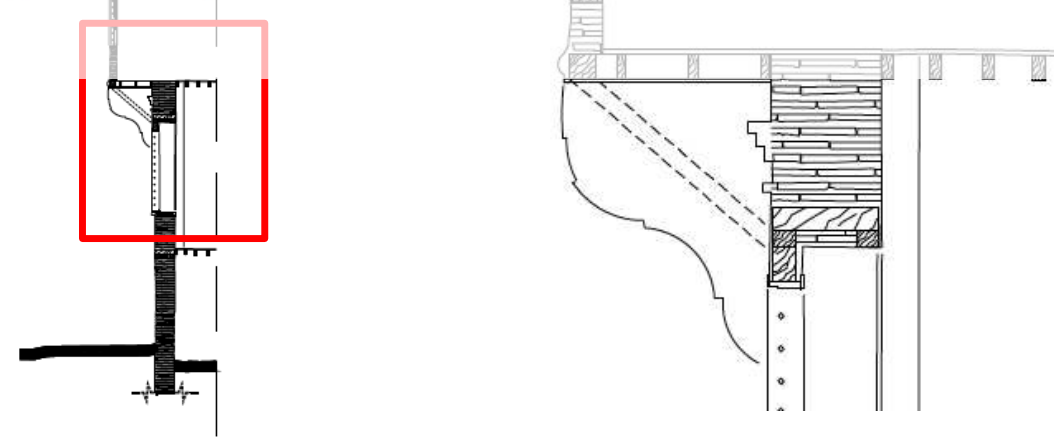

Figure 3: Adana-Tepebağ case study house: On the right, system detail, and on the left timber floor, loadbearing wall and oriel joint detail are shown $[1,13]$.

\subsection{Damage Analysis}

When we examine the structure, there is no clue for the not decadence of the structure. However, from the past to the recent time, the house is faced so many catastrophic events such as Adana-Ceyhan earth-quake in 1998. Therefore, dynamic forces are directly affecting the 
structure, and some of the load-bearing walls got damaged. Timber elements inside of the structure, such as staircases, windows, and doors are decay in time. The structure of the roof got damaged, and the form of the roof is deteriorated as a result of the dynamic forces.

On the ground floor, two rooms are designed on the sides of the plan. The thickness of the masonry walls of the rooms is $40 \mathrm{~cm}$ thick, constructed with mixed brickwork with timber tiebeam support. There is no structural damage to the load-bearing walls. The ceiling is constructed with a timber structure. Primary timber beams are placed parallel to each other with $3,40 \mathrm{~cm}$. distance. Secondary beams that are placed above and perpendicular to the primary beams are constructed $25 \mathrm{~cm}$ parallel to each other. In initial inspection, there is not decadence on the primary and secondary timber beams. However, there is a considerable humidity exposure inside the structure. Therefore, it could be some decay on the corners of the timber beams which are inside of the masonry walls. Also, on the surface of the floor timber finishing material, there had some decay related to humidity. In areas $\mathrm{A}, \mathrm{B}, \mathrm{C}$, and $\mathrm{D}$, which is marked with red lines, there is decay on the surface of the masonry walls related to humidity. Also, in area D, which is marked with blue circular lines, four poles connection detail with ground floor had some decay related to humidity (Figure 4-8). Inside the courtyard, there is a reinforced concrete structure that is built afterward of the historical building [1].
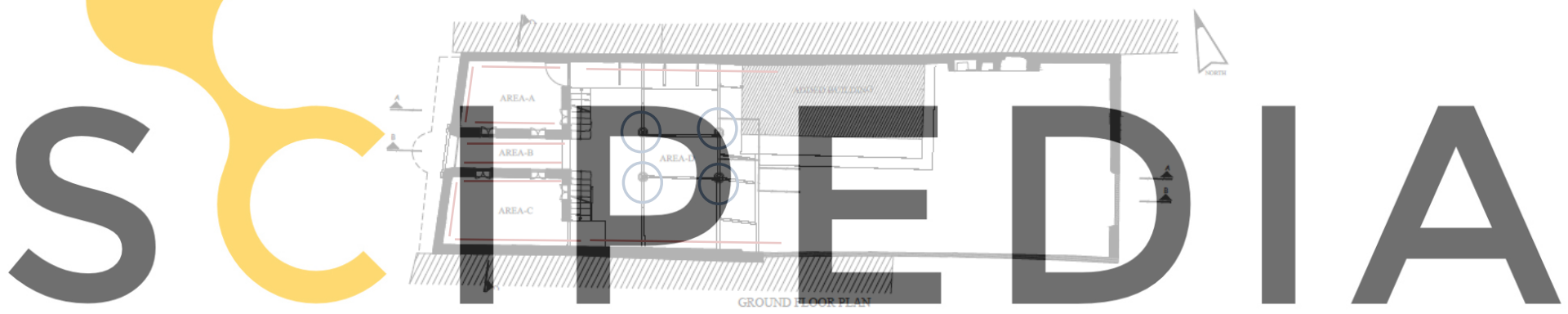

Figure 4: Adana-Tepebağ case study house ground floor plan [1].

Register for free at https//www.scipedia.com to download the version without the watermark On the mezzanine floor, there are cracks and decay on the plasters of the walls, which is marked with red lines. Besides, above the windows and the doors, some deep cracks are related to the load-bearing structure.

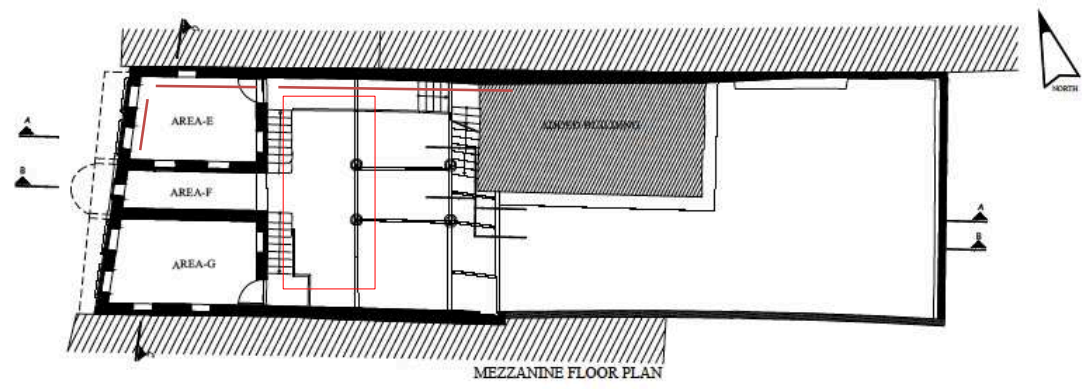

Figure 5: Adana-Tepebağ case study house mezzanine floor plan [1].

The cracks on mezzanine floor are related to the forces which are come in sight with horizontal loads such as seismic activity. Most of the staircases, which are connected ground 
and mezzanine floor, had a considerable decay. Therefore, it needs to be renewed. The timber floor of the courtyard had decay related to humidity, which is marked with a red rectangle [1].

The first-floor slab is supported with timber posts that are located inside of the courtyard. These posts are started from the ground floor and continue to the beneath of first-floor slab timber primarily beams. On the first floor, two brick masonry walls are rested on a timber slab, and there is a critical bending that happened on those beams, which are shown in a purple rectangle (Figure 6-8). The walls which are marked with the light blue line have deep cracks and partially collapsed (Figure 6). There are cracks and decay on the plasters of the walls, which is marked with red lines (Figure 6-7) [1].

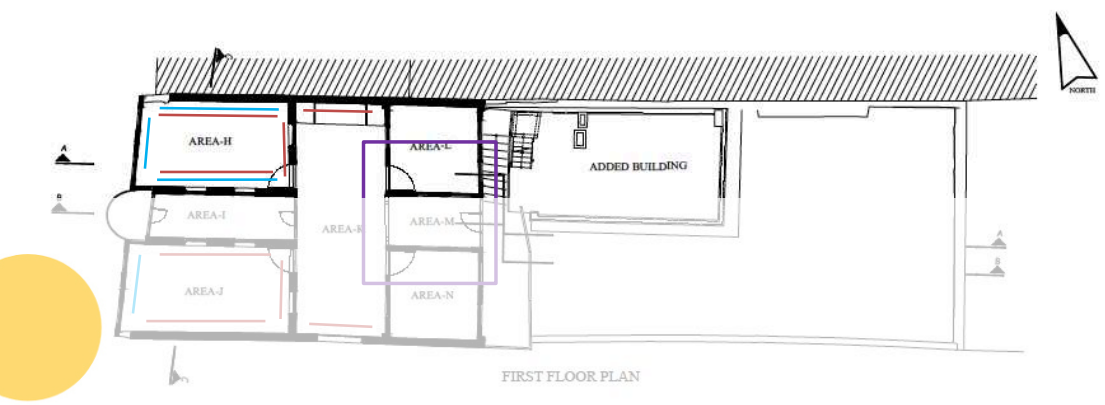

Figure 6: Adana-Tepebağ case study house first-floor plan [1].
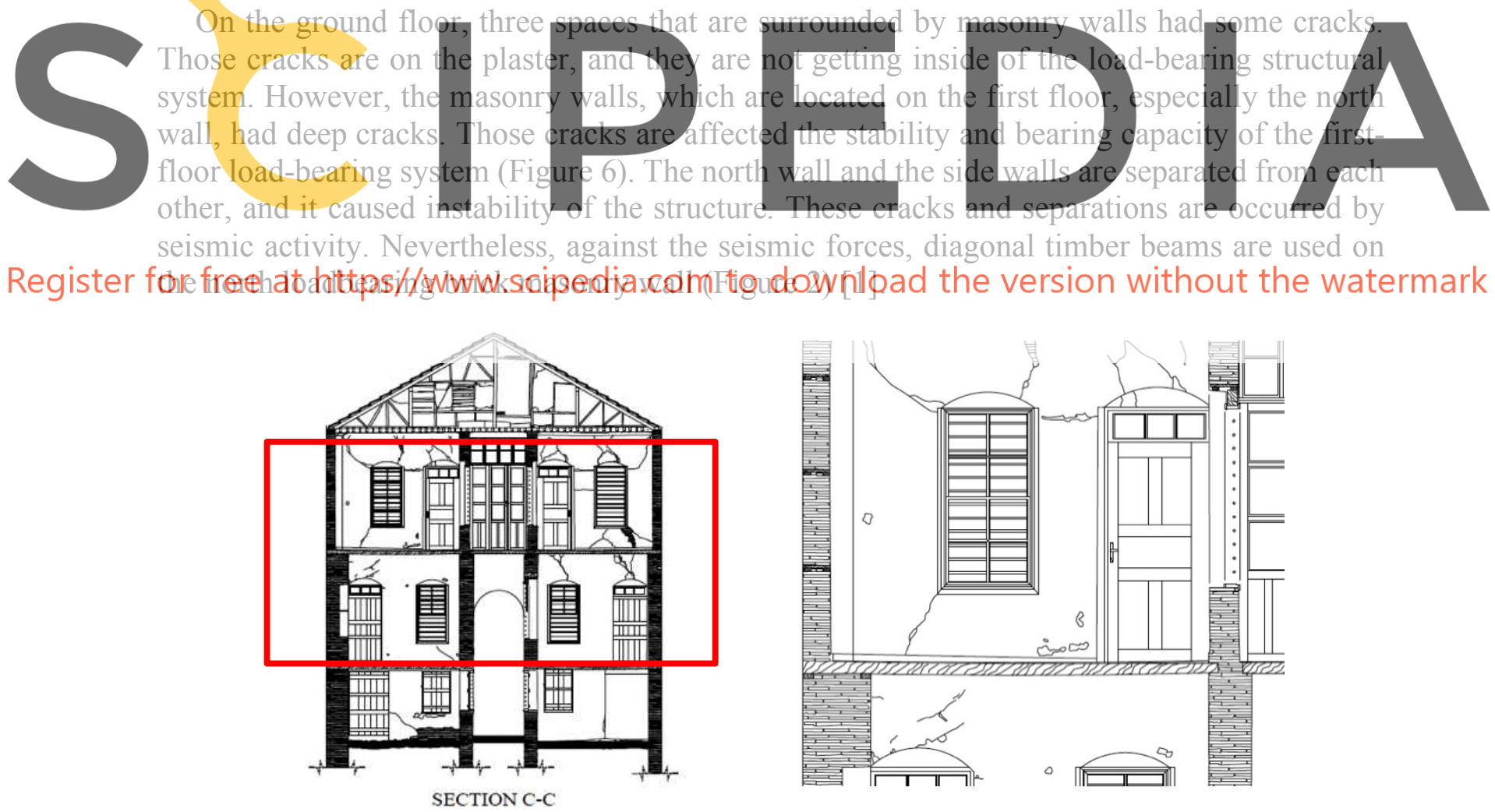

Figure 7: Adana-Tepebağ case study house: On the right section C-C and the left, timber slab, and load-bearing wall joint detail are shown [1]. 
The structural timber elements of the roof were decayed as a result of water, humidity, and solar radiation. The water on the roof is not drained adequately and get out of the building. Therefore, the whole structure, especially timber, is under the effect of corrosion [1].

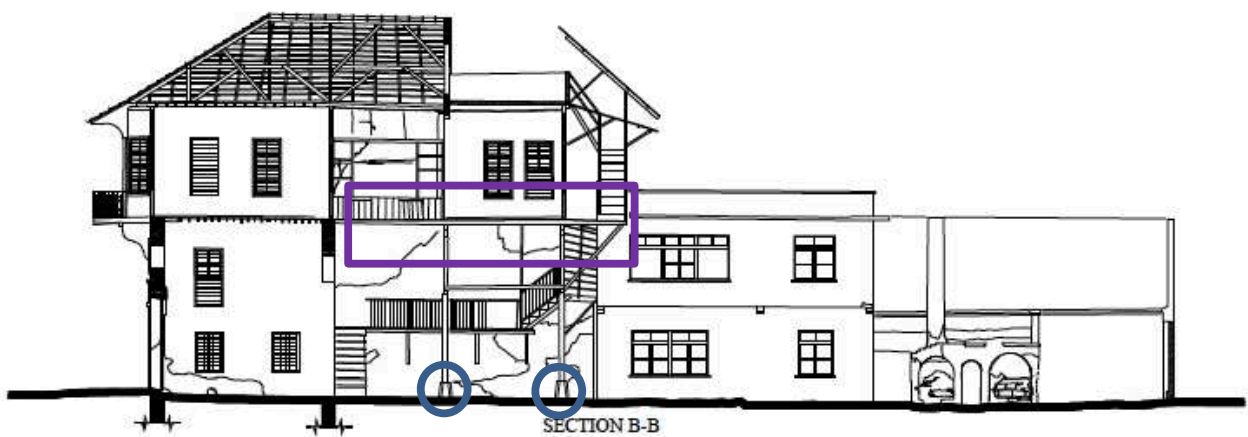

Figure 8: Adana-Tepebağ case study house: On the right section C-C (Adana endowment office) and the left timber slab and load-bearing wall joint detail are shown [1].

\section{METHODOLOGICAL APPROACH OF THE CASE STUDY}

Damage analysis of the three-floor load-bearing structure constructed with a timber frame filled with mixed brickwork is done in the previous chapter. The proper conservation approach is decided according to data received from damage analysis and technological parameters of the contemporary timber prefabrication with the principles of conservation of wooden built heritage by ICOMOS international wood committee in December 2017, Delhi, India.

According to the Ic

related to this research.

day materials and technologies. Some crucia
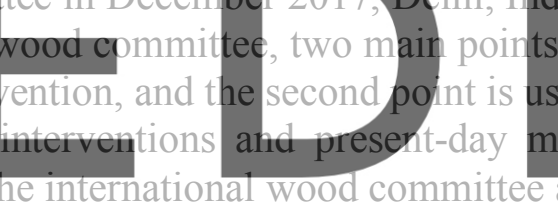

technologies criteria of the timber structures by the international wood committee are listed on the following sentences [9].

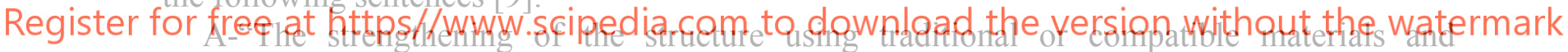
techniques" [9].

B-"Interventions should foliow the criteria of the minimal interventions capabie of ensuring the survival of the construction, saving as much as possible of its authenticity and integrity, and allowing it to continue to perform its function safely" [9].

$\mathrm{C}$-"Be the minimum necessary to ensure the physical and structural stability and the longterm survival of the structure or site as well as its cultural significance" [9].

D-"Be reversible, if technically possible," [9].

E- "Repairs carried out-in situ and on original elements would require an unacceptable degree of intervention" [9].

F-"As much as possible of the existing members should be retained" [9].

G-"New members or parts of members may be discreetly marked, so that they can be identified at a later date" [9].

H-"Present-day materials and technologies should be chosen and used the greatest caution and only in cases where the durability and structural behavior of the materials and construction techniques have been satisfactorily proven over a sufficiently long period" [9]. 
The methodology of conservation with prefabricated timber elements is analyzed with technological criteria's and their suitability with ICCOMOS timber committee ideals. As it is mentioned, in Adana-Tepebağ settlement, traditional historical houses have specific construction details. The structural system of those houses is generally composed of a timber skeleton system with a mix of load-bearing walls. Some of the structural systems are under the effect of big moments, which caused a failure of the parts of those structures. Modern timber prefabricated systems are composed of construction units such as walls, floors, and roofs. Fabricated composite timber beams and columns are considered as prefabricated elements. The units and components can be fabricated in different dimensions and specifications, such as durability and strength. Prefabricated timber systems are essential for decreasing the cost of construction as well as for the conservation in terms of rapid assembly and reaching the high construction quality.

In this methodology, original materials and joint details of the structure are trying to keep. However, for the deteriorated and the loss parts, replacements are done with modern prefabricated units. Modern prefabricated systems are not fit for the compatibility and traceability criteria of the structure. For the reversibility criteria, modern prefabricated structures have possibilities of permeability of intervention with the original one [3].

Using original joints and material is essential for keeping the authenticity of the structure. Modern prefabricated systems are not compatible with this ideal. However, under the risk of loss of significant cultural heritage, this methodology could be a solution. The deteriorated elements could be replaced, and the continuity of the structure is maintained with the use of prefabricated units and

The proposed interve of prefabricated timber the following table 2 -

Table 2: Proposed intervention of damage 'A'
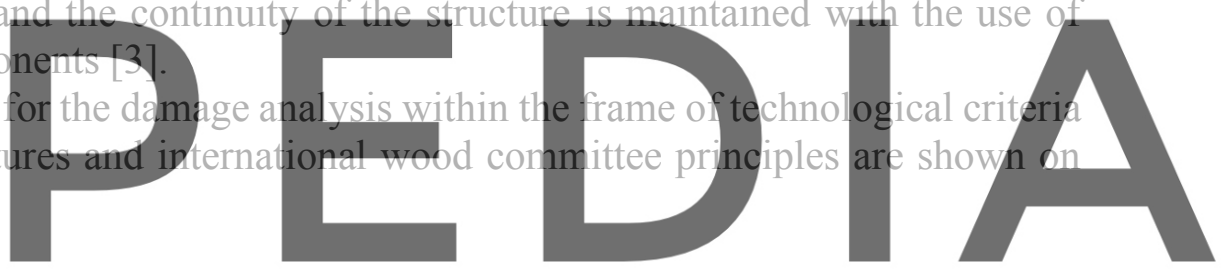

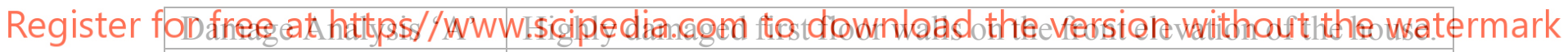

Proposed intervention On the mezzanine floor, masonry has deep cracks on critical points

\begin{tabular}{|l|l|} 
& $\begin{array}{l}\text { of the walls, such as the upper part of windows and doors. } \\
\text { Therefore, first floor damaged walls are proposed to replace with } \\
\text { structural insulated panel or platform wall systems for providing a } \\
\text { lightness to the entire structure. Also, the proposed wall system } \\
\text { provides high strength with adequate thermal isolation parameters, } \\
\text { which provide comfort criteria. }\end{array}$ \\
\hline $\begin{array}{l}\text { Technological } \\
\text { principles of } \\
\text { prefabricated timber } \\
\text { structures }\end{array}$ & $\begin{array}{l}\text { Those systems are compatible with technological principles; } \\
\text { however, lightness and the durability of the prefabricated walls are } \\
\text { the essential points for decision. }\end{array}$ \\
\hline $\begin{array}{l}\text { ICOMOS, } \\
\text { International Wood } \\
\text { Committee Principles }\end{array}$ & Coherent with the principles. \\
\hline
\end{tabular}


Table 3: Proposed intervention of damage 'B'

\begin{tabular}{|l|l|}
\hline Damage Analysis 'B' & $\begin{array}{l}\text { Deflection of first floor primarily timber beams and decay of } \\
\text { secondary beam's corners within the sockets of loadbearing } \\
\text { structure. }\end{array}$ \\
\hline Proposed intervention & $\begin{array}{l}\text { Masonry on the first floor is occurring o pointed load up on the } \\
\text { timber beams and caused deflection. Therefore, replacing them with } \\
\text { structural insulated panel wall or platform wall systems is proposed. } \\
\text { This deflection occurs a deformation on primarily timber beams. } \\
\text { Deflected primarily timber beams replaced with timber 'I' beams } \\
\text { that have high strength ratio and durability. Timber 'I' beams can } \\
\text { support secondary timber beams, floor finish materials, and walls } \\
\text { that are rested on them. }\end{array}$ \\
$\begin{array}{l}\text { Decay of secondary beams which are lost their support function are } \\
\text { replaced with similarly specified beams. }\end{array}$ \\
\hline $\begin{array}{l}\text { Technological } \\
\text { principles of } \\
\text { prefabricated timber } \\
\text { structures }\end{array}$ & $\begin{array}{l}\text { Those systems are compatible with technical regulations. The usage } \\
\text { of timber 'I' beam is brought and present-day material look and high } \\
\text { strength and durability. Besides, lightness and the durability of the } \\
\text { prefabricated walls are the crucial factors for structure. }\end{array}$ \\
\hline $\begin{array}{l}\text { ICOMOS, } \\
\text { International Wood } \\
\text { Committee Principles }\end{array}$ & \begin{tabular}{l} 
Coherent with the principles. \\
\hline
\end{tabular} \\
\hline
\end{tabular}

Table 4: Proposed intervention of damage ' $\mathrm{C}$ '

\begin{tabular}{|l|l|}
\hline Damage Analysis 'C' & Deep and shallow cracks and decay poles. \\
\hline Proposed intervention & $\begin{array}{l}\text { The shallow cracks on the walls are on the plaster, and they are not } \\
\text { related to structural behavior. They can maintain easily. However, } \\
\text { deep cracks are entirely associated with masonry load-bearing } \\
\text { structures. Therefore, replacing timber tie beams are an essential } \\
\text { intervention to prevent those cracks. } \\
\text { Decay of timber poles are risky for providing a long-term strength } \\
\text { for the structure. Those timber poles are very critical for the } \\
\text { structure, which is supporting half part of the first floor. Therefore, } \\
\text { it is necessary to replace them with impregnated timber beams. }\end{array}$ \\
\hline $\begin{array}{l}\text { Technological } \\
\text { principles of } \\
\text { prefabricated timber } \\
\text { structures }\end{array}$ & $\begin{array}{l}\text { Timber tie beams can be impregnated for atmospheric conditions. } \\
\text { Therefore, they can process in a factory. Thus, timber tie beams and } \\
\text { poles are compatible with technological principles. }\end{array}$ \\
\hline $\begin{array}{l}\text { ICOMOS, } \\
\text { International Wood } \\
\text { Committee Principles }\end{array}$ & Coherent with the principles. \\
\hline
\end{tabular}

\section{CONCLUSIONS}

The historic urban site of the Tepebağ settlement is losing its authentic characteristics and importance for the lack of maintenance of the traditional timber houses in a long time. The 
conservation projects of this settlement are prepared with traditional construction techniques that need considerable amounts of workforce, construction cost, and time. Therefore, there is a need for a consolidation method for these historical houses. According to the methodology, the findings of damage analysis and their examination under the comparison charts, building plans and sectional layouts, judgment about the losses, and their causes are clearly defined. The technological parameters and their comparison chart give a general format and decision method for proper structural systems. All those findings provide a general idea for the conservation of historical structure. However, principles for the conservation of wooden built heritage by the ICOMOS international wood committee, gives the borderlines of conservation. With all of those analysis, parameters, and principles, the proposed materials for maintain and conserve the historical timber structure is decided.

This research is significant and unique for its approach related to contemporary timber materials, assembly techniques, and their usage for conserving traditional load-bearing timber frame houses of Adana-Tepebağ. In the future, this research topic can be expended with instrumental analysis of humidity, temperature, decay of structural elements, and their conservation and maintenance with contemporary timber materials.

\section{REFERENCES}

[1] Adana Endowment office, Documentation related to case study inventory number:152, (2016).

[2] Apak, K. Ahşap strüktürel sistem seçim modeli ve geleneksel Kıyıköy konutları üzerinde değerlendirilmesi - Decision methodology of timber structural system and evaluation on Klyıköy settlement. PhD Thesis, Mimar Sinan Fine Arts University, (2009).

[3] Croatto, G., Turrini U. Restoration of historical timber structures -Criteria, innovative solutions and case studies, Seminario Intervir em construçoes existentes de madeira, (2014).

[4] Çelik, Ç. XIX. yy'dan günümüze Adana'da konut mimarisinin gelişimi-The evaluation of Adana's dwelling architecture from XIXth century till today, Ç.Ü. Master Thesis (1999).

[5] Durukan, İ., Karaman, F., Saban, D., Erman, O. Adana, Inventory of urban cultural heritage (2004-2005). TÜBA-KED 7/ (2009).

[6] Eldem, S.H. Türk evi-Turkish house, TAÇ Vakfı Yayınları, (1987).

[7] Halaçoğlu, Y. Adana tarihçesi, Adana köprü başı - History of Adana, Adana köprü başı, Y.K.Y. Yay, (2000), s.11-12.

[8] Herzog, T., Natterer, J., Schweitzer, R., Volz, M., Winter, W. Timber construction manual, Birkhauser, (2004).

[9] ICOMOS International Wood Committee. Principles for the conservation of wooden built heritage, Adopted by ICOMOS at the $19^{\text {th }}$ General Assembly in Delhi, India, (2017).

[10] Kafesçioğlu, R. Kuzey - Batı Anadolu'da ahşap ev yapılart - Timber houses in north-west Anatolia, İ.T.Ü., (1955).

[11] Ökesli, S.D. Herman Jansen's planning principles and his urban legacy in Adana, Metu JFA, (2009), pp.45-67

[12] Özmen, Ö., Geleneksel Adana evleri, Adana köprü başı - Traditional Adana houses, Adana köprü başı, Y.K.Y. Yay, (2000).

[13] Umar, N. Photography inventory related to Adana-Tepebă̆, (2010). 